\title{
Special rights in property: why modern African economies are dependent on mineral resources
}

\author{
Keith Breckenridge
}

Historians have explained the importance of mining in Africa in many different ways. The most important - and most common - of these has been the speculative rewards offered by the investment markets in London, or, in relation to oil, the global commodity markets. In these accounts, the undeniable attractions of metropolitan profits have motivated and sustained investors, managers and governments in the pursuit of African mineral resources. Other scholars have focused on the strategic importance of resources like uranium, gold or oil to account for the determination of the British, French and American governments to secure access to African mineral resources. Looking for local determinants, many historians have pointed to the neat fit between the labour requirements of mining and the labour mobilizing powers of indirect rulers. More recently scholars have shown how the systems of oscillating long-distance migrant labour have drawn upon, and reproduced, the gendered household roles and expectations (Ally 1994, Harries 1994, Moodie 1994, Hecht 2002). All of these explanations have real explanatory power, but in this chapter I want to draw attention to another feature of mineral resources which distinguishes them from the other assets in the continent's economy: the simplicity, precision and consistency of property rights in mineral resources.

In this chapter, I first consider whether mineral resources are, in fact, very important in the workings of modern African economies, weighing them up against the other, much more popular, domains of economic activity. I then turn to a history of mining development, offering a five-stage periodization in order to account for the special place of mining in many African economies. The chapter tries to show that the developmental benefits of mining, such as they are, have been restricted to a special kind of metal mining, and that diamond and oil extraction are unlikely to repeat them. But I do also offer a wider conceptual explanation for the importance of mining in many African economies. Running 
through all of these stages of mining history is, I think, a much simpler and more definite form of property than is otherwise available in Africa. I argue that it is this special form of property right that has sustained mining as the dominant source of foreign investment in many African economies.

\section{The significance of mineral resources in African economic history}

The current UNCTAD World Investment Report makes the point succinctly: almost all of the $\$ 36$ billion that African economies attracted in Foreign Direct Investment in 2006 was directed at the exploitation of 'oil, gas and mining' resources. The 2006 figure is more than double the total for 2004, and it reflects global corporate interest in the mineral resources of the continent. One striking feature of these current capital flows is the unprecedented involvement of Asian corporations who make up a quarter of the spending; another is the investment of some $\$ 8$ billion in the mining resources of the poorest countries on the continent. Sudan, Equatorial Guinea, Chad, Tanzania, Ethiopia, Zambia, Uganda, Burundi, Madagascar and Mali all attracted 'investors seeking new mining locations in response to rising global demand and high commodities prices' (UNCTAD 2007). Yet the problem of African economic dependence on minerals is more paradoxical than it first appears.

Foreign investment is a fickle indicator of the key characteristics of national economies. This current round of global interest in the mining assets on the continent dates only from the turn of the current century, and it marks a very welcome end to the long commodities slump that began for most industrial metals in the mid-1970s, and for gold and oil a decade later. That slump, as Ferguson has shown for the Copperbelt, was experienced by many people employed in the largest mining industries in Zambia, Congo, Namibia and South Africa as a traumatic failure of the 'plotline of development'. We would, I suspect, have been worrying about a very different problem of dependency just ten years ago when copper (and many other commodity) prices had hit their historical nadir, and thousands of urban Zambians were returning to the countryside (Ferguson 1999: 256).

The geology of Africa is also misleading. In his 1986 economic history of the continent, Wickins warned of the false promise of the mineral remedy, reminding us that of all the countries on the continent only a quarter have valuable mineral reserves, and 'fewer than a tenth have considerable deposits of oil' (Wickins 1986: 310). The geological picture for oil has changed a little with the discovery of new fields in Chad, Equatorial Guinea and tiny Sao Tomé and Principe, but Wickins' point retains its essential power. In Sub-Saharan Africa the oil fields are concentrated in the Gulf of Guinea, a tight band of mostly offshore fields from Cabinda, the Angolan exclave province that collars the Congo, to the Niger Delta. Similarly, mining investment has been overwhelmingly concentrated in southern Africa and in the Central African copperbelt (Frankel 1969). There 
are countries - such as Angola and Nigeria - that have valuable mining and oil reserves, but most African countries have neither.

The predominance of mineral resources in the investment (and export) figures for the continent reflects the fact that the most important economic activity - subsistence farming - is officially insignificant. The absence of investment, or significant exports, from farming, which employs three-quarters of the people on the continent and contributes only a third of GDP, reflects farmers' pervasive withdrawal from the market (World Bank 2007: 3). As Berry has demonstrated, the economically defensive stance that most African farmers assume is the product of a century of systematic uncertainty and indecision in the state's attitude to agriculture (Berry 1993). The recent World Bank decision to focus on a green revolution in Africa is correct and laudable, but it also risks adding yet another episode of official interference to a century of confusion (World Bank 2007).

Informal trade is the other key area of economic activity on the continent and, by definition, it rarely features in official economic statistics. Yet there can be little doubt that trade, much of it illegal, is more significant for the real workings of African economies, and their citizens, than mining (MacGaffey 1991). Measuring economic activity that often seeks to exploit the value-gaps created between states is no simple matter; 'national frontiers in Africa', Ellis and Macgaffey observe, 'may themselves be considered a resource' (Ellis and MacGaffey 1996: 32). Yet trade is undeniably critical across the continent. The ubiquitous opportunities for subsistence trading contribute to the flimsy hold that farmers maintain over their labourers (and their family members) (Berry 1993). Illegal trade is also closely bound to the wholesale looting of state assets that has been common across the continent: Bayart has correctly observed that official corruption and illegal trade are 'indivisible spheres' of the same activity (Bayart 1993: 237). The very worthlessness of national currencies provides a compelling imperative for increased trade, as traders must carry goods on both legs of their desired exchange (Ellis and MacGaffey 1996). Viewed across the half-millennium, trade (in gold, slaves and ivory) has always provided the most important opportunities for accumulation on the continent (Curtin 1984, Thornton 1992). Yet, in the modern era, what is striking about the illegal trade is how much of the high-value, and politically significant, trade is conducted in mining products (consider the significance of the illegal diamond trade for Mobuto, Savimbi and Taylor).

The importance of mineral products in African trade is not new; gold long defined the continent's integration into the world economy. Some of the gold coins minted in Egypt in the first and second centuries BC had their origin in gold mines in the Sudan and, after the expansion of camel trading two hundred years later, gold from West Africa began to make its way into the Roman monetary system. By the sixth century we can speak of a 'flourishing gold trade' across the Sahara (Garrard 1982: 446-7, 452). When the Portuguese first began 
to seek out Sub-Saharan ports in the fourteenth century they famously sought the source of the African gold trade in order to circumvent the Arab monopoly on the desert trade; the initial object of their search was the Senegal, the River of Gold (Thornton 1992: 28-30). It was gold that both drew the Europeans to West Africa, and provided the means for the development of some of the largest West African states, like the Asante (McCaskie 1983: 26, Wilks 1977). In the centuries after the initial Portuguese contact it was the slave trade, and slavery, that dominated trade, and transformed African societies, but in the era of colonial rule, from 1880 to the end of the 1950 s, mining came to occupy the centre stage of the African economy.

The thesis of Frankel's comprehensive 1939 survey of capital investment in Africa was that 'mining has been the touchstone of economic development in most of Africa'. Writing from Johannesburg during the boom brought on by the abandonment of the Gold Standard in 1933, his survey stressed the Witwatersrand's comparative success in alleviating the poverty of the region. For Frankel, the harnessing of European capital, and science, to the massed labour of Africans, held out the promise of a great social transformation of the continent: the areas of the continent 'most advanced economically are those whose main activities rest on mineral exploitation'. He had in mind here the region running from the Congo to the Cape, but he also highlighted the significance of mine exports from Sierra Leone (diamonds), Nigeria (tin) and the Gold Coast (gold).

The key to African development for Frankel, partly in agreement with W. Arthur Lewis, was the displacement of the 'money crops for export' with heavily capitalized mineral extraction. In an interesting reverse on the current concern about mineral resources, mining was the obvious remedy to the market vulnerability and glacial economic progress of what he called the agricultural 'monocultures'. He was optimistic of the prospects for mining investment as the engine of development. As things turned out, the overall project of colonial development was a failure; the officials who were responsible for the plans, and the funding, in London (and Paris) began to realize that the costs of colonial social welfare would greatly exceed the returns. Frankel's study was written at the beginning of the crisis of decolonization, a process that would see the European powers abandon their hold on the continent 'in a single generation' (Frankel 1969: 210, 214-15, Cooper 1996: 395-6). He was dumbfounded (as he noted in the second edition published in 1969) by the rapidity of the decolonization process but in one respect he was correct: mining resources throughout the continent continued to attract large investments between 1940 and the late 1960s, and both the colonial and the post-colonial states adopted his idea that mineral exploitation could serve as the engine of development. 


\section{Periodizing the developmental character of mineral exploitation}

Over the course of the last century the character of mining capital in Africa, and its political relationship with the state, has undergone some startling changes. Let me list them schematically now: mining exploitation started out as the province of merchants; between the De Beers launch in 1886 and the First World War, African mining projects were sucked into the speculative markets of the City often without real production of any kind. In the same period, enormous capital flows and the special conditions on the Witwatersrand prompted the development of massive vertically integrated industrial corporations; outside of South Africa these corporations worked with the colonial state in the 1920s to drive the developmental project of a stabilized African proletariat. This developmental emphasis was adopted by the post-colonial states with a growing preoccupation after 1970 with Africanization and nationalization; by the end of the 1980s a new era of enclave mining had become entrenched, where the development of mineral resources was radically isolated from the wider economy and society.

I think these shifts are intrinsically interesting, and that they help to make sense of the resilience and flexibility of mining capital in Africa, but I want to examine them now to make a different analytical point: what distinguishes mineral investment in Africa, running like a thread through all of the different forms that mining capital has taken over the last century, is the centrality of an uncontested property right (or concession or license) to the profitability of investment. This ability to define, hold and sell a special kind of legal right in land over the course of the century is, I think, unique in Africa outside of South Africa. From the days of the Chartered Companies to the current oil multinationals, what distinguishes mining investment from almost all other forms of investment in Africa was the ability unambiguously to identify, commoditize and secure property rights. Often mining investment has consisted of nothing other than the securing of those rights.

For the twenty years after the discovery of the diamonds in Kimberley, mining investment lay in the hands of merchant capital. Initially the diamond fields lay formally beyond the legal boundaries of the two white states, so the adventurers who began to pour in to the river and dry diggings (like prospectors everywhere else) drew up their own rules for the ownership of mining claims. The initial camps were chaotically settled but the two later (and more significant) farms on which diamonds were discovered were carefully pegged out by a Free State land surveyor into hundreds of claims measuring exactly 31 feet squared. The diggers resolved that natives could not own claims, that no digger could own more than one claim and that the claim would be forfeited if it was not worked for eight consecutive days, but these regulations were withdrawn by the new British administration in October 1871 (Smalberger 1976: 421-2, Worger 1987: 17). Within months the growing technical difficulties of mining small adjacent properties at depth, the rapidly increasing cost of claims and then the declining price of diamonds began to move the fields into the hands of wealthier 
merchants (see also Turrell 1982: 51-3). By the middle of the 1870 s very large investments by London-based diamond merchants in the Kimberley claims precipitated the consolidation of ownership that led to the formation of the De Beers monopoly (Worger 1987: 35).

Key to this process was an already existing, and very vigorous, market in land in the Cape, a market that was, as Keegan shows, assiduously nurtured by reforming colonial administrators after 1820. The substitution of a system of quit-rent freehold properties for the old loan farm systems that the Dutch East India Company ${ }^{1}$ had used in a largely vain attempt to regulate settler property was the first step in this process. The establishment of a Land Board in 1828, and the appointment of properly qualified land surveyors, marked the beginning of a period of land speculation that led to 'a fully fledged settler capitalism that was to spread well beyond the original settler nucleus in Albany district' (Keegan 1996: 57, 101, 168). This market, and the activities of the merchant investors, extended into the comparatively disheveled economy of the Transvaal Republic as early as the 1850 s, when speculators based in the Cape had bought up the huge lands handed out gratis to Boer settlers (Delius 1983: 128-30).

A different kind of merchant capital dominated mining rights beyond the borders of the white colonies. In places like Nigeria and Zambia the effort to survey, register and secure property was simply beyond the means of imperial administrators. The chartered companies formed at the end of the nineteenth century, modeled in name at least on the seventeenth century monopolies, were initially given extravagant rights of sovereignty over huge territories. The British companies - Royal Niger Company, British East African Company, and Rhodes' British South Africa (BSA) Company - all quickly found themselves caught between the rock of their London investors' expectations and the hard place of profitability in the ceded territories in Africa. Towards the end of the century the Colonial Office also began to see the dangers of designing states around the expectations of London investors and, after allowing the East African company to collapse, both the Niger Company and the BSA Company lost their inflated rights of sovereignty in exchange for a set of claims over land and mineral rights (Slinn 1971: 365-82, Vail 1976, Freund 1981: 32, Young 1994: 61).

Over the course of the twentieth century these mineral rights were to prove immensely profitable for the shells that remained of the chartered companies. Both companies were granted the right to impose an (almost entirely unearned) royalty on the profits of mining that would make them famously profitable right in to the 1960s. What is interesting about these royalty rights is the way in which the Colonial Office maneuvered to defend them - often against the will of their local officials, white settlers and anointed African leaders. In marked contrast to the almost open-ended disputes about land ownership that the system of indirect rule encouraged (Berry 1993), officials in London responded to the claims of the Lozi paramount in 1921 that 'whatever happens we cannot throw doubt on the validity of the concessions'. This determination to protect the legitimacy of the 
royalty was repeated up until the very moment of independence. In Nigeria the Niger Company exercised a similar property right over the large tin mines on the Jos Plateau, allowing them to deduct fully half of all the revenues due to the government up until the Second World War without making any significant contribution to mining (Slinn 1971, Freund 1981: 32, 213-14).

An important feature of this period of merchant dominance was the preoccupation with the profits that could be earned in the City on the basis of the (often fictional) promise of mining profits in Africa. Thousands of companies were formed in London between 1880 and 1914 to exploit claims in South Africa, Ghana and Nigeria, often with little more basis than a legal right to mine. Over five hundred companies were established, with a nominal capital of $£ 43$ million, to exploit resources in West Africa only before 1904; at the time only thirteen companies were producing ore (Frankel 1969: 162-3). A decade later a similar frenzy of speculative investment struck the tin mining properties in Nigeria - $£ 10$ million was invested in an industry that had a total annual product of $£ 650,000$. By the start of the First World War this speculative period had collapsed under the weight of unmet expectations; merchant capital would survive in African mining through the entire century, but increasingly the power to determine both the volume and the object of investment passed into the hands of vertically integrated mining corporations, mostly based in Johannesburg.

Corporations (of the kind that Chandler has studied in the US) began to displace the grip of speculative merchant capital on mining on the Witwatersrand in the late 1880s. The early investors on the Rand were merchants, mostly from the Eastern Cape, looking to repeat the great speculative success of Rhodes' De Beers flotation. They had a very weak understanding of both the geology and the technology of deep level mining and very quickly faced bankruptcy (Webb 1981). It was the introduction of large numbers of American mining engineers, mostly under the influence of Hamilton Smith and the Rothschild's Exploration Company - and massive investments of capital from Kimberley and London that changed the long-term character of mining gold and diamonds in South Africa. By the start of the 1920s mining in South Africa was dominated by three very large corporations - Rand Mines, Consolidated Gold Fields, and AngloAmerican - all of which were formed under the management of American engineers (Marks and Trapido 1979, Turrell and Van Helten 1986, Katz 1999, 2005).

Key to this process of incorporation was the certainty of mining rights. Twenty years later the key American engineers remembered the 'liberal and definite' mining law of the old Transvaal in explicit contrast to the complex 'Apex Law' that bedeviled property rights in the United States (Rickard 1922: 231). 'A striking feature of the mining [in the Transvaal] was the absence of litigation', the American consulting engineer for one of the key German investors remembered:

The Witwatersrand mining area comprises a stretch of country now about 50 miles long by 2 to 3 miles wide, covered from end to end with mining claims grouped 
into mining properties in active operation and often controlled by men of different nationalities, yet a mining lawsuit is a practically unheard of thing, while those that have occurred during the past twenty years can be counted on the fingers of one hand. This is eloquent testimony to the practical efficiency of a mining law that limits the four sides of a mining claim by vertical planes. (Rickard 1922: 264)

In this respect (and many others) the old Transvaal provided a laissez faire greenhouse that fostered the new mining corporations. Ironically, the managers who demanded that the Boer state change to a more thoroughly rationalized economy would later look back to the 1890 s with nostalgic regret.

A key feature of this era of corporate dominance of gold mining, which clearly distinguishes it from the later periods, was a very ambitious project of social transformation that the mining engineers, and their companies, demanded from the Boer and British governments. Briefly, the (mostly American) managers in charge of the new gold mining companies sought the establishment of a properly capitalist agriculture and railways, an efficient and autonomous state, and a set of coercive labour regulations (and policing institutions) designed to bind the contracted workforce to their employers. Many of the demands made by the mining industry were actually being met the State Attorney, Jan Smuts, as Sir Alfred Milner determined to go to war with the Transvaal in order to secure them (Chamber of Mines 1897, Marks and Trapido 1979).

The war between Britain and the Boer republics, devastating as it undeniably was for the people of the platteland, formed an important part of this social transformation. The British government spent extraordinarily lavishly in the effort to defeat small numbers of highly mobile Boers. The $£ 220$ million spent by the British government between December 1899 and May 1902 contrasts eloquently with the $£ 1$ million annual budget for the entire empire under the terms of the 1940 Colonial Development and Welfare Act. Much of this huge sum was spent in South Africa on provisioning and transportation but also on railway, harbour and policing infrastructure (Worsfold 1913). After 1901 the boundary problems that have confronted African states (Herbst 2000) for most of the last century were incomprehensible in South Africa. Milner also spent heavily on the extension of the railway system and the introduction of scientific agriculture and irrigation systems. Some of the funding for this very expensive project came from a low interest development loan of some $£ 35$ million but most was derived from a new 10 percent profits tax on the mining industry (a precedent that would serve as the basis of the South African government's subsidization of local industry and agriculture in the late 1920s) (Denoon 1973: 42).

There is, of course, a bundle of paradoxes here. Africans paid a heavy price, politically and economically, for the new society. They were taxed heavily, and received only a tiny proportion of that tax back in education subsidies or infrastructure. Labour controls, segregation of the land and population growth remorselessly weakened the basis of what, in the late nineteenth century, had been vibrant peasant agriculture (Beinart 1982, Bundy 1988). By the end of the 
Depression (as the gold-mining industry inherited the unearned bounty from the sterling devaluation and the new mines of the Orange Free State were being opened up for development), the corporations exercised an almost uncontested economic and political domination over the 400,000 migrants who worked in the mines (Breckenridge 1995). After the 1922 strike African workers were locked in to the least organized and skilled jobs. In the long run these constraints on African economic activity doomed the prospects of growth.

Yet it is also true that the developmental preoccupations of the South African state between 1900 and 1950, reinvigorated by the Nationalists' determination to foster domestic industry in order to employ poor whites in the 1920 s, made it possible for the country partially to heal itself of the 'Dutch disease' (Feinstein 2005: 113-35). Gold-mining certainly funded much higher levels of imports than would have otherwise been possible: through most of the twentieth century gold earned between 40 and 75 percent of the country's exports. But over the long term - a process that took the better part of half a century - the resources for the development of the country's heavy industry came from the state revenues derived from the gold mines (Yudelman 1983). This income from gold came in part from mineral rights which retained the state's ownership of gold-bearing ore and required companies to purchase the right to mine through a system of leases. The real revenue windfall followed the passing of the Excess Profits Tax in 1933 in the official reaction to the Hertzog government's forced abandonment of the Gold Standard (Katzen 1964: 55-60). Perhaps more important than revenue, although much more difficult to measure, the establishment of the Wits School of Mines, under the patronage of the American mining engineers, produced hundreds of scientifically and technologically innovative engineers whose work in the corporations, para-statals and universities secured the diversity of South Africa's industrial economy (Dubow 2006: 235-44).

In the rest of the continent, South African corporate power had less dramatic but similarly complex effects on the economic place of mining. In Nigeria, Consolidated Gold Fields was one of a small number of imperial mining houses that set out to dominate a tin mining industry that employed nearly 100,000 workers by the 1940s. More importantly, it was the great financial success of the South African companies, especially before 1914, that encouraged the flood of speculative investment into the West African mining companies (Freund 1981: 30-8). In Zambia the boundary between the BSA chartered company and the increasingly dominant South African corporations began to blur in the late 1920s when Anglo, with the support of the American Newmont Corporation, became the consulting engineers for the new copper mines and the dominant shareholder in the chartered company (Gregory 1962: 384-412, Slinn 1971). Something very similar occurred in the Nigerian tin-mining industry (Freund 1981: 222-3). Throughout this period, the managerial and research expertise of the South African industry, and of the Chamber of Mines in particular, shaped mining on the rest of the continent (Crisp 1983). The most important of the 
interventions of the South African mining corporations was clearly the string of monopsonistic contracts set up by the De Beers corporation with the colonial governments of Angola, Congo, Gold Coast, Guinea, Sierra Leone, Tanganyika, and Namibia. Again, the key to the success of these agreements was the legal form of mineral rights in the colonies. 'The production from the foreign countries, such as Angola, Congo, and Sierra Leone', Ernest Oppenheimer explained to the board of the Diamond Producers' association in 1934, 'was completely controlled by reason of the government concessions given to the companies in respect of the whole of the territories concerned' (Gregory 1962: 319, 329, 371-2). De Beers' position as the monopoly wholesaler meant that outside of southern Africa it had little interest in the organization of diamond production, or its developmental costs and benefits (aside from the effort to curtail illicit diamond mining and trading after 1960). In metal mining, especially on the Rhodesian copperbelt, the situation was different.

Professions of the importance of the 'cause of national development' were, interestingly, often matched by significant infrastructural investments outside of mining in the period between 1940 and 1960. By the early 1950s, Anglo American had consolidated its control of the Zambian copperbelt, which was producing about 10 percent of the total global output in an industry that was dominated by a small number of very large and powerful American corporations (Schmitz 1986). Anglo moved the headquarters of its Central African subsidiary, primarily to avoid British taxes, to the capital of the new Rhodesian Federation. Sir Ernest Oppenheimer's public promise that Anglo would 'take a leading part in assisting the progress of the Rhodesias' was promptly fulfilled by the purchase of $£ 5,000,000$ of rolling stock rented to the state railways and the provision of a $£ 20,000,000$ loan, and a further $£ 10,000,000$ power surcharge levied on the mines, for the financing of the Kariba hydro-electric dam (Gregory 1962: 461-6).

By the 1940s, mining had become the most important site (indeed often the only site) of the colonial states' new and concerted development effort. This effort, as Fred Cooper has shown, was unlike the mainly infrastructural projects planned by the American mining engineers on the Rand in the 1890s; it turned - under the contradictory influence of Labour and social Catholic Party officials in London and Paris, and workers in Africa and the West Indies - on the planned implementation of welfare benefits aimed at the building of modern African families (Cooper 1996). Key to this project was the 'stabilized' African workforce of the mines and railways, and especially the social laboratory of the Central African copperbelt. In both the Congo and the Zambian copperbelt the initial system of labour migrancy, modeled on the tax and pass regimes of the Witwatersrand, were abandoned in the 1920s for a permanent population of workers and their families. In the Congo this involved comprehensive, and invasive, medical interventions supported by the church and the mining corporation, Union Miniere du Haut Katanga (UMHK), in order to lower infant 
mortality (Hunt 1999: 251-3). On the Zambian copperbelt, the British government's search for a new kind of urban African family produced the RhodesLivingstone Institute in 1940, one of the key sites for the production of social scientific understandings of an emerging African industrial modernity.

The growing militancy and organization of mine workers in the British territories in the 1940s routinely complicated the plans carefully laid in the colonial office, and the pressure to defuse workers' protests led remorselessly towards improved social benefits. Even the anemic gold mines in Ghana began to provide subsidized housing and electricity, improved medical care, and a variety of sports and recreation facilities under pressure from local officials (Crisp 1984: 72-5). This welfarist slant to mining development continued apace through the 1950s (and well in to the 1960s) as Cold War-inflated prices for metal commodities gave the corporations and their host governments the resources to spend on increased wages, pensions, housing, education and entertainment (Freund 1981: 218). In the copperbelt, government and mining companies funded the construction of 100,000 houses between 1948 and 1864; in Eastern Nigeria the new local ministers began a program of free, universal primary school education (Berry 1993: 55, Ferguson 1999: 66). To help fund these interventions, the Colonial Office at last bought out (at the expense of each colony) the licensing revenues of the chartered companies in Southern Rhodesia, Nigeria and, at the very last moment, Northern Rhodesia (Freund 1981: 213-14).

In the wake of Mau Mau, the Colonial Office began to dwell on the arithmetical implications of the social interventions being promoted in London and Africa. As the prospects of sustaining locally administered and locally funded welfare interventions darkened, officials began to view self-government as a way out of an increasingly intractable mess. 'The people are going to be disillusioned,' the Governor-General of Nigeria wrote in 1955, 'but it is better that they should be disillusioned as a result of the failure of their own people than that they should be disillusioned as a result of our actions' (Cooper 1996: 393). It was not long before the post-colonial states that inherited the new expenses of lateimperial welfarism battened on to the resources, and particularly the precious foreign exchange, offered by mineral exports.

A new era of nationalized mining began in 1959 when Nkrumah bought out six marginal gold mines and set up the State Gold Mining Corporation (Crisp 1984: 133). Towards the end of the decade, Kenneth Kaunda nationalized 51 percent of the equity of the two corporations, Zambian Anglo American and Roan Selection Trust, on the copperbelt (Ferguson 2006: 197, Libby and Woakes 1980). The Zambian president hoped that by vesting mineral rights in his own office he would be able to encourage the newly nationalized corporations to increase investments and expand mining beyond copper. In 1973, Kaunda announced a program of Zambianization to fill managerial positions, and the positions of key decision makers, with nationals. At about the same time the military governments in Ghana and Nigeria bought majority share holdings in 
the few remaining mining companies, and sought to implement programs of 'indigenization' (Freund 1981: 224, Tsikata 1997). In most of these cases, the mining corporations seem not to have offered anything by way of significant resistance.

In the Congo, the process of nationalization was much more ragged. Immediately after Belgium had hastily granted the Congo its independence, UMHK funded the three-year secession of the Shaba copperbelt region, earning the enmity of the otherwise pro-capitalist dictator who seized power in 1965, Mobuto Sese Seko. Mobuto seized UMHK on the first day of 1967, briefly incurring the wrath of the International Association for the Protection and Promotion of Private Foreign Investments and a team of US diplomats; two weeks later he accepted the advice of the US diamond merchant, Maurice Tempelsman, to enter into negotiations with the Belgian company about the terms of nationalization. What is striking about this period is that Mobuto, despite the intense international competition in the copper industry, could find no buyer for the expropriated assets of the corporation. Faced with the complete withdrawal of skilled personnel from the copperbelt, rapid depletion of the country's foreign exchange and a global boycott of Congolese copper organized by the Société General de Belgique, Mobuto was forced to allow UMHK to continue operating the mines, stripped of their property rights in the subterranean copper. It was only with the development of the Tenke Fungurume (TFM) cobalt and copper mines in 1971 that Mobuto, and Tempelsman, were able to achieve their aim of breaking UMHK's stranglehold on the Zairian copperbelt (Gibbs 1997).

An important, and easily forgotten, feature of this period of nationalist economic policy was the massive investment that African governments made in the effort to create new transport linkages. In Gabon, in 1972, President Bongo commissioned a $650 \mathrm{~km}$ railway line linking Libreville on the coast with the mining district at Franceville on the eastern side of the country. Twelve years later it was opened. The line, which cost the massive sum of $\$ 4$ billion and requires an operating subsidy of sum $\$ 60$ million per annum, was built by some of the largest rail contractors in Europe; to date it seems not to have had any measurable developmental benefit for non-mining regions it passes through (Reed 1987). On the other side of the continent, China provided an interest-free loan and the contractors to build the Uhuru Railway connecting Dar-es-Salaam with the copperbelt, allowing the Zambian mines to export without having to use the Rhodesian and South African networks or the war-ravaged Benguela line. Here, again, the massive investment in infrastructure has produced very little developmental result. The Tazara line runs through vast tracts of Tanzania that have very low population densities, and the railway has struggled to retain the expert mechanical staff required to maintain diesel locomotives and the line itself. For many years trains have run infrequently and very slowly (Due 1986). In Nigeria the federal government spent lavishly on the building of all-weather roads in the 
middle of the oil boom. Road construction was famously subject to the special '40 percent' enabling fees that became common in Nigeria in this period, but the real problems were cost over-runs caused by inflation and the very large numbers of new vehicles that were imported after the salary increases of the mid-1970s (Freund 1978). Perhaps the most eloquent of the infrastructure projects of this period was the Ingba dam scheme commissioned by Mobuto Sese-Seko to provide electricity to the Shaba copperbelt mines. The cost of the dam, which was built by American contractors, rose from an initial estimate of $\$ 260$ million to well over $\$ 1$ billion seven years late. And the 1,800km transmission line, which Mobuto sought to use to control the secessionists in Shaba, quickly fell prey to scavengers looking for sources of high-quality scrap metal. With the exception of the Tazara line, these projects were all built by the leading consulting firms in Europe and America: no one seems to have mentioned that the financial and managerial burden of maintaining the infrastructure was likely to exceed the capacity of the new states (Young and Turner 1984).

The overtly developmental objectives of the nationalization period were, of course, not met. Instead these continent-wide processes synchronized with the resurgence of what Bayart has called 'the politics of the belly' (1993). Nationalization of the mining companies in Ghana, Nigeria, Congo and Zambia and the global decline in mining commodity prices usually (although not always) resulted in a precipitous decline in production; everywhere it has strengthened the politics of the gatekeeper state in the post-colonial period. This process was double-sided. 'If the state intrudes as a gatekeeper for the multinationals,' Bill Freund observed twenty-five years ago, 'it does so as well for the mass of Africans in the humbler pursuit of basic goods and services' (1998: 247). For Bayart, the leveling features of the politics of the post-colonial state which sees the little men extracting concessions from the rich and powerful and one political faction replaced by another without any meaningful prospect of accumulated wealth and power for either - prevent him from viewing the gatekeeper state as an instrument of exploitation. But he does acknowledge that the importance of factional struggles in the period of nationalization underscores the resurgence of a new kind of merchant capital in Africa, dominated by 'a Bruce Mackenzie or a "Tiny” Rowland in Eastern and Southern Africa, or of a Maurice Tempelsman in Zaire or of a Jamil Said Mohammed in Sierra Leone' (Bayart 1993: 216).

The period of nationalization in mining began to unravel quite rapidly toward the end of the 1980s. With encouragement from the World Bank, thirty African countries had changed their mining codes to allow for the return of private foreign investment by 1987 (Reno 1997). Ghana was amongst the first to begin this process of privatizing nationalized mineral assets, leading to the sale of some 80 percent of the state's equity in the Ashanti Goldfield Corporation in 1994, most of which went to Lonrho. In the Congo, Zambia and Tanganyika private mining companies have begun to buy hundreds of mining leases or 
state-owned properties. In the process a new kind mining development, heavily influenced by the explosion of investment in off-shore oil drilling in Angola, Equitorial Guinea, Gabon and Nigeria, seems to be taking shape.

The gold, cobalt and copper mines that are currently under development in central Africa are unique historically owing to their enclave character. The new very large gold mines in western Tanzania, for example, have almost no infrastructural connection to the rest of the country. These mines have built their own power generation, water supply, housing for skilled ex-patriots and airstrips. The catering for the employees on some of the central African mines is arranged with companies in South Africa who fly almost all the mine provisions from Johannesburg. Aside from increased tax revenues (no small matter for many African countries) it seems unlikely that this kind of mining will produce any of the wider industrial or infrastructural benefits that followed in southern Africa in the first half of the twentieth century. But what is striking in all of these cases is the comparative simplicity, and certainty, of the mineral rights purchased by these new mining companies, even, as has usually been the case, where hundreds of nationals have been earning a subsistence income in artisanal mining. The model of this new form of mining investment seems to be the massive off-shore oil developments owned and often operated by the thirty-year-old Angolan oil parastatal, Sonangol (de Oliveira 2007, Ferguson 2006: 194-210).

\section{Conclusion}

The importance of mineral extraction in twentieth-century African economies is, obviously, a product of the relative formal weakness of the other forms of economic activity on the continent. But the problem is not simply one of relative economic significance; mining is qualitatively different to the other areas of economic activity on the continent. Mines are important, especially to foreign investors and African states, because it is very difficult to extract, and accumulate, capital in agriculture, trade and industry. It is difficult to resist the conclusion that mining worked in the twentieth century throughout much of Africa because, like eighteenth- and nineteenth-century slavery, it was 'the only form of private, revenue-producing property in African law' (Thornton 1992: 74).

Mining worked very well under the political economy of colonial rule. The labour demands of mining synchronized much better with the politics of indirect rule than the special skills of secondary industry or the coercive requirements of agriculture. Almost all of the continent's mines raised their initial workforce through the agency of African customary authorities working as agents of the colonial state (Freund 1981: 55-7, 138). Mining, especially compounded mining, fed off the gendered character of labour resources in African households. At least before the 1970s, millions of African men sought short-term opportunities to earn cash wages in the, often vain, hope of building a more prosperous rural home. They traveled very great distances from their own 
home districts to secure these jobs (Gordon 1977, Beinart 1982, Harries 1994, Moodie 1994).

Mining was also well suited to the peculiar transport infrastructure of colonial Africa; most colonial (and post-colonial) railway lines - Milner's marketoriented trunk lines are the exception here - run from a key regional port to the source of the most valuable minerals. 'All roads and railways led down to the sea', as Rodney noted in 1972. 'They were built to extract gold or manganese or coffee or cotton.' The continued importance of mining, at least until the recent period, reflected the enduring economic effects of that extractive transport infrastructure (Rodney 1981: 209). For the gatekeeper state, under colonial rule and afterwards, mining was an irresistible source of power and weakness (Cooper 2002: 156-90).

For over a century it has been the global commodity markets that have periodically drawn foreign investors to African mineral resources. That is as true today as it was in the 1890s. It is well to remember, as South Africa's Finance Minister Trevor Manuel noted in 2007, that the current mining boom, like the others before it, is not 'a permanent shift [but] a temporary opportunity' (Manuel 2007). The history of the last century of mining in Africa also demonstrates that the developmental benefits of mining have declined dramatically over time. Perhaps it is time to apply the lessons of the security, simplicity and fungibility of mineral rights to other forms of property, and other industries.

\section{References}

Ally, Russel (1994). Gold and Empire:The Bank of England and South Africa's Gold Producers, 1886-1926, Johannesburg: Witwatersrand University Press

Bayart, Jean-Francois (1993). The State in Africa:The Politics of the Belly, London: Longman

Beinart, William (1982). Political Economy of Pondoland, 1860 to 1930, Johannesburg: Cambridge University Press

Berry, Sara (1993). No Condition Is Permanent:The Social Dynamics of Agrarian Change in Sub-Saharan Africa, Madison, WI: University of Wisconsin Press

Breckenridge, Keith (1995). “"Money with dignity”: migrants, minelords and the cultural politics of the South African gold standard crisis, 1920-33', Journal of African History 36(2): 271-304

Bundy, Colin (1988). Rise and Fall of the South African Peasantry, Cape Town: David Philip

Chamber of Mines, Witwatersand (1897). The Mining Industry, Evidence and Report of the Industrial Commission of Enquiry, with an Appendix, Johannesburg

Cooper, Frederick (1996). Decolonization and African Society: The Labor Question in French and British Africa, Cambridge: Cambridge University Press

Cooper, Frederick (2002). Africa since 1940: The Past of the Present, Cambridge: Cambridge University Press

Crisp, Jeff (1983). 'Productivity and protest: scientific management in the Ghanaian gold mines, 1947-1956’, in Frederick Cooper (ed.), Struggle for the City: Migrant Labor, Capital and the State in Urban Africa, Beverly Hills, CA: Sage Publications

Crisp, Jeff (1984). Story of an AfricanWorking Class: Ghanaian Miners' Struggles, 1870-1980, London: Zed Books 
Curtin, Philip D. (1984). Cross-Cultural Trade in World History, New York: Cambridge University Press

de Oliveira, Ricardo Soares (2007). 'Business success, Angola-style: postcolonial politics and the rise and rise of Sonangol', Journal of Modern African Studies 45(4): 595-619

Delius, Peter (1983). Land Belongs to Us:The Pedi Polity, the Boers and the British in the Nineteenth Century Transvaal, Johannesburg: Ravan Press

Denoon, Donald (1973). A Grand Illusion:The Failure of Imperial Policy in the Transvaal Colony During the Period of Reconstruction, 1900-1905, London: Longman

Dubow, Saul (2006). A Commonwealth of Knowledge: Science, Sensibility, and White South Africa, 1820-2000, New York: Oxford University Press

Due, John F. (1986). 'Trends in rail transport in Zambia and Tanzania', Utafiti 8(2): 43-58

Ellis, Stephen and Janet MacGaffey (1996). 'Research on sub-Saharan Africa's unrecorded international trade: some methodological and conceptual problems', African Studies Review 39(2): 19-41

Feinstein, Charles H. (2005). An Economic History of South Africa: Conquest, Discrimination, and Development, New York: Cambridge University Press

Ferguson, James (1999). Expectations of Modernity: Myths and Meanings of Urban Life on the Zambian Copperbelt, Berkeley, CA: University of California Press

Ferguson, James (2006). Global Shadows: Africa in the Neoliberal World Order, Durham, NC: Duke University Press

Frankel, Sally Herbert (1969). Capital Investment in Africa, New York: Howard Fertig

Freund, Bill (1978). 'Oil boom and crisis in contemporary Nigeria', Review of African Political Economy 5(13): 91-100

Freund, Bill (1981). Capital and Labour in the Nigerian Tin Mines, Atlantic Highlands: Humanities

Freund, Bill (1998). The Making of Contemporary Africa:The Development of African Society since 1800, Boulder, CO: Lynn Riener

Garrard, Timothy F. (1982). 'Myth and metrology: the early trans-Saharan gold trade', Journal of African History 23(4): 443-61

Gibbs, David (1997). 'International commercial rivalries and the Zai'rian copper nationalisation of 1967', Review of African Political Economy 24(72): 171-84

Gordon, Robert (1977). Mines, Masters and Migrants: Life in a Namibian Compound, Johannesburg: Ravan Press

Gregory, Theodor (1962). Ernest Oppenheimer and the Economic Development of Southern Africa, Oxford: Oxford University Press

Harries, Patrick (1994). Work, Culture and Identity: Migrant Labourers in Mozambique and South Africa, c.1860-1910, Johannesburg: Witwatersrand University Press

Hecht, Gabrielle (2002). 'Rupture-talk in the nuclear age: conjugating colonial power in Africa', Social Studies of Science 32(5-6): 691-727

Herbst, Jeffrey (2000). States and Power in Africa: Comparative Lessons in Authority and Control, Princeton, NJ: Princeton University Press

Hunt, Nancy Rose (1999). A Colonial Lexicon of Birth Ritual, Medicalization, and Mobility in the Congo, Durham, NC: Duke University Press

Katz, Elaine N. (1999). 'Revisiting the origins of the industrial colour bar in the Witwatersrand gold mining industry, 1891-1899’, Journal of Southern African Studies 25(1): 73-97

Katz, Elaine (2005). 'The role of American mining technology and American mining engineers in the Witwatersrand gold mining industry 1890-1910', South African Journal of Economic History 20(2): 48-82

Katzen, Leo (1964). Gold and the South African Economy, Cape Town: Balkema

Keegan, Timothy (1996). Colonial South Africa and the Origins of the Racial Order, Cape Town: David Philip 
Libby, Ronald and Michael Woakes (1980). 'Nationalization and the displacement of development policy in Zambia', African Studies Review 23(1): 33-50

MacGaffey, Janet (1991). The Real Economy of Zaire:The Contribution of Smuggling and Other Unofficial Activities to National Wealth, Philadelphia: University of Pennsylvania Press

Manuel, Trevor (2007). The Standard, 23 September. Available at www.thestandard.co.zw/ business/12228.html (accessed 3 February 2011)

Marks, Shula and Stanley Trapido (1979). 'Lord Milner and the South African state', History Workshop Journal 8(1): 50-80

McCaskie, Tom C. (1983). 'Accumulation, wealth and belief in Asante history. I. To the close of the nineteenth century', Africa: Journal of the International African Institute 53(1): 23-79

Moodie, T. Dunbar (1994). Going for Gold: Men, Mines and Migration, Berkeley, CA: University of California Press

Reed, Michael C. (1987). 'Gabon: a neo-colonial enclave of enduring French interest', Journal of Modern African Studies 25(2): 283-320

Reno, William (1997). 'African weak states and commercial alliances', African Affairs 96 (383): 165-186

Rickard, Thomas A. (1922). Interviews with Mining Engineers, San Francisco

Rodney, Walter (1981). How Europe Underdeveloped Africa, Washington, DC: Howard University Press

Schmitz, Christopher (1986). 'The rise of big business in the world copper industry', Economic History Review 39(3): 392-410

Slinn, Peter (1971). 'Commercial concessions and politics during the colonial period: the role of the British South Africa Company in Northern Rhodesia, 1890-1964', African Affairs 70(281): 365-84

Smalberger, John M. (1976). 'The role of the diamond-mining industry in the development of the pass-law system in South Africa', International Journal of African Historical Studies 9(3): 419-34

Thornton, John K. (1992). Africa and Africans in the Making of the Atlantic World, 1400-1680, Cambridge: Cambridge University Press

Tsikata, Fui S. (1997). 'The vicissitudes of mineral policy in Ghana', Resources Policy 23 $(1-2): 9-14$

Turrell, Robert (1982). 'Kimberley: labour and compounds, 1871-1888', in Shula Marks and Richard Rathbone (eds) Industrialisation and Social Change: African Class Formation, Culture and Consciousness 1870-1930, London: Longman, pp. 45-69

Turrell, Robert and Jean-Jacques Van Helten (1986). 'The Rothschilds, the Exploration Company and mining finance', Business History 28(2): 181-205

UNCTAD (2007). 'World Investment Report: Transnational Corporations, Extractive Industries and Development', New York and Geneva: UNCTAD.

Vail, Leroy (1976). 'Mozambique's chartered companies: the rule of the feeble', Journal of African History 17(3): 389-416

Webb, A. C. M. (1981). 'Witwatersrand Genesis: A Comparative Study of Some Early Gold Mining Companies, 1886-1914', Doctorate, Rhodes University

Wickins, Peter (1986). Africa: An Economic History, 1880-1980, Oxford: Oxford University Press

Wilks, Ivor (1977). 'Land, labour, capital and the forest kingdom of Asante: a model of early change', in Jonathan Friedman and M.J. Rowlands (eds) Evolution of Social Systems, Pittsburgh, PA: Pittsburgh University Press, pp. 487-529

Worger, William H. (1987). South Africa's City of Diamonds: MineWorkers and Monopoly Capitalism in Kimberley, 1867-1895, New Haven, CT: Yale University Press

World Bank (2007). 'World Bank assistance to agriculture in sub-Saharan Africa: an IEG review', Independent Evaluation Group, Washington, DC: World Bank 
Worsfold, W. Basil (1913). The Reconstruction of the New Colonies under Lord Milner, byW. BasilWorsfold, Vol. 2, London

Young, Crawford (1994). The African Colonial State in Comparative Perspective, New Haven, CT:Yale University Press

Young, Crawford and Thomas Turner (1984). The Rise and Fall of the Zarian State, Madison, WI: University of Wisconsin Press

Yudelman, David (1983). The Emergence of Modern South Africa: State, Capital, and the Incorporation of Organized Labour on the South African Gold Fields, 1902-39, Cape Town: David Philip

\section{Notes}

1 Often referred to by its Dutch acronym, VOC (Vereenigde Oostindische Compagnie). 